\title{
Persoons- en ziektegebonden factoren geassocieerd met de verzuimduur na COVID-19
}

Marloes van Stralen, Erik Noordik, Corné Roelen

COVID-19

SARS-CoV-2

return to work

predictors

person-related factors

disease-related factors

\section{Inleiding}

COVID-19 staat voor Corona Virus Disease (20)19 en is een nieuwe infectieziekte. Het virus behoort tot de categorie van Severe Acute Respiratory Syndrome related Coronavirus (SARS-CoV-2) en lijkt zowel genetisch als in de praktijk het meest op het SARS-coronavirus uit 2003. ${ }^{1}$

Op 27 februari 2020 werd een eerste geval van de infectieziekte COVID-19 in Nederland gemeld en al snel nam het aantal besmettingen in Nederland toe. ${ }^{2}$ Tot 1 juni 2020 was er in Nederland een beperkte testcapaciteit beschikbaar. Hierdoor kon niet bij alle mensen met klachten een COVID-19-infectie vastgesteld dan wel uitgesloten worden, waardoor er mogelijk meer besmettingen zijn geweest dan uit de cijfers blijkt. Op 11 maart 2020 verklaarde de World Health Organization (WHO) COVID-19 tot pandemie, een epidemie op wereldwijde schaal. $^{3}$

In mei 2020 gaf het Centraal Bureau voor de Statistiek (CBS) aan dat het verzuimpercentage onder werknemers in het eerste kwartaal was gestegen van 4,7\% in 2019 naar $5,2 \%$ in 2020 , het hoogste verzuim sinds 2003. Deze toename deed zich voor in alle bedrijfstakken. Werknemers in de gezondheidszorg en industrie verzuimden het meest. ${ }^{4}$ Wat de impact van dit hoge verzuim op de lange termijn zal zijn, is nog onduidelijk. Maar dat er druk kwam te staan op de bedrijfsvoering binnen deze bedrijfstakken mag duidelijk zijn, zeker omdat het cruciale
Drs. M. (Marloes) van Stralen, aios Bedrijfsgeneeskunde, Arbo Unie, locatie Rotterdam/ Europoort

Dr. F.W. (Erik) Noordik, sr. adviseur/opleider en docent onderzoekscholing Netherlands School of Public \& Occupational Health (NSPOH), Utrecht

Prof. dr. C.A.M. (Corné) Roelen, bedrijfsarts Arbo Unie en hoogleraar Bedrijfsgeneeskunde i.h.b. Verzuim en Werkfunctioneren Rijksuniversiteit Groningen, Universitair Medisch Centrum Groningen, afdeling Gezondheidswetenschappen, Sociale Geneeskunde

Dit onderzoek is uitgevoerd als onderdeel van de opleiding tot arts Arbeid en Gezondheid bij de NSPOH

Correspondentieadres: marloes.van.stralen@arbounie.nl beroepen betreft die nodig waren voor de bestrijding van de coronacrisis.

In dezelfde periode berichtte de NOS dat duizenden mensen met een al dan niet bevestigde COVID-19-infectie thuis zitten en wekenlang ziek blijven. Deze ziektegevallen werden ten onrechte als mild afgegeven en er was nog geen adequate nazorg voor deze patiënten. Zowel het Rijksinstituut voor Volksgezondheid en Milieu (RIVM) als het Nederlands Huisartsen Genootschap (NHG) onderkenden deze problemen. ${ }^{5}$ Ook uit de spreekuurcontacten van bedrijfsartsen bleek al dat patiënten na een COVID-19-infectie langdurig klachten kunnen houden, zoals verminderde energie en verminderde conditie. Er is echter nog vrijwel geen onderzoek gedaan naar factoren die van invloed zijn op de verzuimduur door COVID-19.

Het doel van dit onderzoek is om te achterhalen welke persoons- en ziektegebonden factoren geassocieerd zijn met de verzuimduur als gevolg van COVID-19-infectie. De bedrijfsarts zou met deze kennis actief navraag kunnen doen naar de relevante factoren tijdens de verzuimbegeleiding en betere prognoses en adviezen kunnen geven aan zowel werkgever als werknemer.

\section{Methode \\ Opzet}

Er is een cross-sectioneel onderzoek gedaan. Deelnemers vulden een vragenlijst in met vragen over de verzuimduur en de persoonsgebonden en ziektegebonden factoren die volgens het RIVM relevant zijn voor COVID-19.1

\section{Populatie}

Bedrijfsartsen gebruiken vanaf 1 april 2020 de CAScode R605 bij verzuim met een bewezen of hoge verdenking op COVID-19. Op 1 september 2020 werd een selectie gemaakt uit het verzuimsysteem van Arbo Unie naar alle lopende en afgesloten ziekmeldingen met CAScode R605 tot en met 31 augustus 2020. Het betrof 1065 werknemers, die een uitnodigingsemail ontvingen met het verzoek om een vragenlijst in te vullen wanneer er sprake is geweest van een bewezen of hoge verdenking op een COVID-19-infectie. 


\section{Samenvatting}

Doel: Welke factoren zijn geassocieerd met de tijd tot volledig herstel bij werknemers die verzuimen door een COVID-19-infectie?

Methode: In een cross-sectioneel onderzoek zijn 349 werknemers geïncludeerd die waren ziekgemeld in verband met COVID-19. Zij vulden eenmalig een vragenlijst in over persoons- en ziektegebonden factoren en verzuim. Associaties met de verzuimduur zijn geanalyseerd met univariate en multivariate Cox-regressieanalyses. Een hazard ratio $(H R)<1$ duidt op een kleinere kans op herstel, ofwel een langere verzuimduur.

Resultaten: Van de persoonsgebonden factoren zijn mannelijk geslacht, overgewicht en roken geassocieerd met langere verzuimduur. Van de ziektegebonden factoren zijn vermoeidheid, spierpijn, kortademigheid, gastro-intestinale klachten, reuk- en/of smaakverlies en ziekenhuisopname geassocieerd met een langere verzuimduur. Bij multivariate analyse blijken kortademigheid en roken de belangrijkste voorspellers van lang verzuim met COVID-19.

Conclusie: Geadviseerd wordt dat bedrijfsartsen in de anamnese kortademigheid en rookgedrag uitvragen en daarnaast aandacht besteden aan vermoeidheid, spierpijn, gastro-intestinale klachten, reuk- en/of smaakverlies en ziekenhuisopname om de verzuimduur bij COVID-19 in te schatten.

\section{Dataverzameling}

Met de factoren die volgens het RIVM relevant zijn voor COVID-19 werd een vragenlijst samengesteld die als pilot is doorlopen door drie artsen en een projectleider met deskundigheid op het gebied van vragenlijsten. Daarna is de vragenlijst gebruiksklaar gemaakt voor werknemers. Werknemers ontvingen bij de uitnodiging e-mailinformatie over het onderzoek, wat deelname aan het onderzoek betekende en hoe er met de verzamelde gegevens wordt omgegaan. Daarnaast kregen zij een directe link naar de vragenlijst. Als de werknemer op de link klikte, werd toestemming verleent voor deelname.

De antwoorden op de vragenlijst werden verzameld en verwerkt in overeenstemming met de Algemene Verordening Gegevensbescherming (AVG). De items woonplaats en geboortedatum zijn veranderd in respectievelijk woonprovincie en geboortejaar om er zeker van te zijn dat de data niet tot een persoon herleidbaar zijn. De deelnemers werden niet blootgesteld aan behandelingen en/of belastende gedragingen. Daarom is vastgesteld dat WMO-toetsing niet noodzakelijk was.

\footnotetext{
Variabelen

In de vragenlijst zijn persoonsgebonden gegevens, ziektegebonden gegevens en verzuimgegevens uitgevraagd. Voor persoonsgebonden gegevens zijn geslacht, leeftijd, hoogst afgemaakte opleiding (lager onderwijs, middelbaar onderwijs, mbo, hbo en wo), lengte en gewicht uitgevraagd. De body mass index (BMI) is berekend met de uitgevraagde lichaamslengte in meters en het lichaamsgewicht in kilogram. De BMI-scores zijn conform de WHO-criteria ingedeeld in ondergewicht (BMI <18.5),
}

normaal gewicht (BMI 18.5-24.9), overgewicht (BMI 25.0-29.9) en obesitas (BMI $\geq 30$ ). ${ }^{6}$ Aangezien er maar vier deelnemers met ondergewicht waren, is deze categorie samengevoegd met normaal gewicht. Verder zijn een aantal leefstijlfactoren gemeten met de vragen: rookt $u$ ? (ja, nee gestopt, nee nooit gerookt), drinkt $u$ alcohol? (ja, nee) en sport u? (ja, nee).

Om vast te stellen of er sprake was van COVID-19 zijn de vragen gesteld: bent u getest op COVID-19? (ja, nee), en was de test positief op COVID-19? (ja, nee). Deelnemers werd gevraagd welke symptomen (koorts, verkoudheid, keelpijn, hoesten, vermoeidheid, hoofdpijn, kortademigheid, spierpijn, gastro-intestinale klachten als diarree en misselijkheid, en reuk- en/of smaakverlies) ze hadden. Ten slotte zijn vragen gesteld over ziekenhuisopname (ja, nee) en aantal verzuimdagen. De verzuimdagen zijn gebruikt voor de effectmaat (tijd-tot-volledig-herstel).

\section{Data-analyse}

Voor de data-analyse is gebruikt gemaakt van SPSS, versie 25. Om te bepalen welke factoren samenhangen met de tijd tot volledig herstel is Cox-regressieanalyse uitgevoerd. De relatieve risicomaat is de hazard ratio (HR), met een $95 \%$ betrouwbaarheidsinterval (BI) en een $\mathrm{p}$-waarde. Een $\mathrm{HR}<1$ geeft aan dat er een kleinere kans is op volledig herstel in de tijd, ofwel een langere verzuimduur. Een HR $>1$ geeft aan dat er een grotere kans is op volledig herstel in de tijd, ofwel een kortere verzuimduur. De variabelen die in de univariate analyse een $10 \%$ significantie niveau $(p<0.10)$ hebben zijn geselecteerd voor een multivariate Cox-regressieanalyse. De Wald statistic (regressiecoëfficient gedeeld door de standaardfout) geeft aan in hoeverre een variabele in multivariate analyse een stabiele voorspeller is van de verzuimduur.

\section{Resultaten}

Er zijn 349 (33\%) vragenlijsten ingevuld; in tabel 1 worden de belangrijkste kenmerken van de onderzoekspopulatie weergegeven. De gemiddelde leeftijd van de onderzoekspopulatie was 49.7 (standaarddeviatie SD 10.5) jaar en $51 \%$ van de populatie was vrouw. Het merendeel van de deelnemers is mbo of hoger opgeleid. Bij $66 \%$ van de deelnemers was sprake van overgewicht (40\%) of obesitas (26\%). Van de deelnemers rookt 7\%, gebruikt 59\% alcohol en sport $65 \%$.

Van de 349 deelnemers hebben 190 (56\%) een COVID-test gehad en daarvan zijn er 126 positief getest. De klachten die het vaakst gemeld zijn tijdens een $\mathrm{CO}$ VID-19-infectie, zijn vermoeidheid (92\%), koorts (78\%) en kortademigheid (78\%). De gemiddelde verzuimduur was 79.1 (SD 63.1) dagen. Van de 349 deelnemers waren 178 deelnemers (51\%) volledig hersteld ten tijde van het invullen van de vragenlijst. In figuur 1 is de Kaplan-Meier-curve weergegeven. Daarin is te zien dat $70 \%$ van de deelnemers na een maand, 56\% na twee maanden 
Tabel 1.

Kenmerken van de studiepopulatie

\section{Variabele}

Geslacht - Man

Geslacht - Vrouw

Leeftijd (in jaren)

Opleidingsniveau

\begin{tabular}{|l|r|}
\hline Lager en middelbaar onderwijs & $50(15 \%)$ \\
MBO & $111(33 \%)$ \\
\hline
\end{tabular}

$\mathrm{HBO}$

WO

Missend

BMI-klassen

Normaal

Overgewicht

Obesitas

Missend

Roken - Ja

Roken - Gestopt

Roken - Nee

Alcohol - Ja

Alcohol-Nee

Missend

Sporten - Ja

Sporten - Nee

Missend

COVID-test - Ja

COVID-test - Nee

Missend

Positieve COVID-test - Ja

Positieve COVID-test - Nee

Missend

Koorts - Ja

Koorts - Nee

Missend

Verkouden - Ja

Verkouden - Nee

Missend

Keelpijn - Ja

Keelpijn - Nee

Missend

Hoesten - Ja

Hoesten - Nee

Missend

Vermoeidheid - Ja

Vermoeidheid - Nee

Missend

Hoofdpijn - Ja

Hoofdpijn - Nee

Missend

Kortademig - Ja

Kortademig - Nee

Missend

Spierpijn - Ja

Spierpijn - Nee

Missend

Diarree - Ja

Diarree - Nee

Missend

Misselijkheid - Ja

Misselijkheid - Nee

Missend

Reuk- en/of smaakverlies - Ja

Reuk- en/of smaakverlies - Nee

Missend

Opname ziekenhuis - Ja

Opname ziekenhuis - Nee

Missend

$103(31 \%)$
Totale $\mathbf{n = 3 4 9}(\%)$ Gemiddelde (SD)

\section{$170(49 \%)$}

$179(51 \%)$

$55(16 \%)$

$125(36 \%)$

8

$116(34 \%)$

$135(40 \%)$

$89(26 \%)$

9

$26(7 \%)$

$41(12 \%)$

$282(81 \%)$

$204(59 \%)$

$141(41 \%)$

4

$225(65 \%)$

$121(35 \%)$

3

$190(56 \%)$

$148(44 \%)$

11

$126(67 \%)$

$63(33 \%)$

1

258 (78\%)

$73(22 \%)$

18

167 (50\%)

164 (50\%)

18

$198(60 \%)$

133 (40\%)

18

219 (66\%)

$112(34 \%)$

18

$305(92 \%)$

$26(8 \%)$

18

$228(69 \%)$

18

257 (78\%)

$74(22 \%)$

18

229 (69\%)

$102(31 \%)$

18

99 (30\%)

$232(70 \%)$

18

$77(23 \%)$

$254(77 \%)$

18

$170(51 \%)$

$161(49 \%)$

18

49 (15\%)

$282(85 \%)$

18

49.7 (10.5)

Tabel 2.

Resultaten univariate regressieanalyse

Variabele

Leeftijd

Geslacht
Vrouw
Man

Opleidingsniveau

Lager en/of middelbaar onderwijs 1 (referentie)

$\mathrm{MBO}$

$\mathrm{HBO}$

WO

$1.05(0.60,1.84)$

$1.18(0.72,1.92)$

Body Mass Index (BMI)

Normaal gewicht (18.5-24.9)

Overgewicht (25.0-29.9)

Obesitas ( $\geq 30.0$ )

Roken - Nee

Roken - Gestopt

Roken - Ja

Alcohol - Nee

Alcohol - Ja

Sporten - Nee

Sporten - Ja

Positieve COVID-test - Ja

Positieve COVID-test - Nee

Koorts - Ja

Koorts - Nee

Verkouden - Ja

Verkouden - Nee

Keelpijn - Ja

Keelpijn - Nee

Hoesten - Ja

Hoesten - Nee

Vermoeidheid - Ja

Vermoeidheid - Nee

Hoofdpijn - Ja

Hoofdpijn - Nee

Kortademig - Ja

Kortademig - Nee

Spierpijn - Ja

Spierpijn - Nee

Gastro-intestinale klachten - Ja

Gastro-intestinale klachten - Nee

Reuk- en/of smaakverlies - Ja

Reuk- en/of smaakverlies - Nee

Opname ziekenhuis - Ja

Opname ziekenhuis - Nee

1 (referentie)

$0.65(0.49,0.91)$

$p=0.01$ *

$\mathrm{p}<0.01 *$

1 (referentie)

$0.34(0.20,0.58) \quad p<0.01$ *

$0.22(0.11,0.45) \quad p<0.01$ *

1 (referentie)

$1.41(1.03,1.93) \quad p=0.03 *$

\begin{tabular}{l|l}
1 (referentie) & \\
$1.11(0.82,1.52)$ & $p=0.50$
\end{tabular}

1 (referentie)

$1.45(0.92,2.28) \quad p=0.11$

$0.85(0.60,1.19) \quad \mathrm{p}=0.33$

1 (referentie)

$1.17(0.87,1.58) \quad p=0.29$

1 (referentie)

$0.87(0.65,1.18) \quad p=0.38$

1 (referentie)

$1.15(0.83,1.59) \quad p=0.40$

1 (referentie)

$0.52(0.32,0.86) \quad p=0.01$ *

1 (referentie)

$0.84(0.62,1.15) \quad p=0.28$

1 (referentie)

$0.50(0.36,0.70) \quad \mathrm{p}<0.01$ *

1 (referentie)

$0.71(0.52,0.96) \quad p=0.03^{\star}$

1 (referentie)

$0.50(0.36,0.70) \quad p<0.01$ *

1 (referentie)

$0.58(0.43,0.79) \quad \mathrm{p}<0.01^{*}$

1 (referentie)

$0.30(0.14,0.63) \quad p<0.01$ *

(referentie)

$\mathrm{HR}=$ Hazard Ratio; $\mathrm{BI}=$ betrouwbaarheidsinterval;

* meegenomen in multivariate analyse. 
Figuur 1.

Uitstroomcurve bij volledig herstel na verzuim door COVID-19

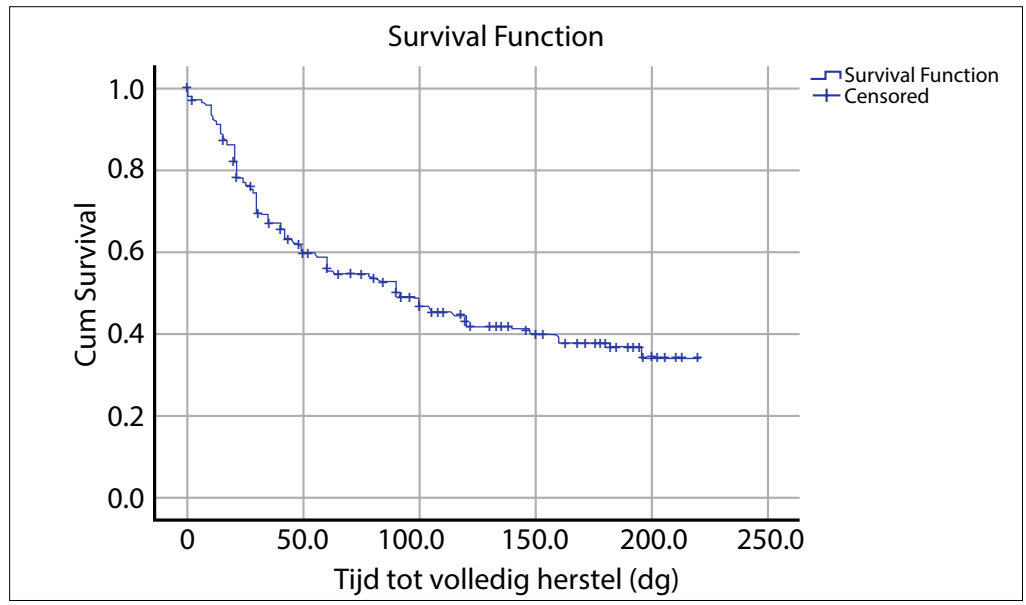

en $50 \%$ na drie maanden nog niet volledig hersteld was; $37 \%$ van de deelnemers was na 6 maanden nog steeds niet volledig hersteld.

Tabel 2 toont de resultaten van univariate Cox-regressieanalyse. Mannen hadden een langere verzuimduur dan vrouwen. Daarnaast waren zowel overgewicht als obesitas geassocieerd met langer verzuim. Mensen die roken hadden een langere verzuimduur en mensen die alcohol dronken hadden een kortere verzuimduur. Leeftijd,

Tabel 3.

Resultaten multivariate Cox regressieanalyse

\begin{tabular}{|c|c|c|c|}
\hline Variabele & HR $(95 \%$ BI) & Significantie & Wald \\
\hline $\begin{array}{l}\text { Geslacht: } \\
\text { Vrouw } \\
\text { Man }\end{array}$ & $\begin{array}{l}1 \text { (referentie) } \\
0.75(0.54,1.04)\end{array}$ & $p=0.09$ & 2.94 \\
\hline $\begin{array}{l}\text { BMI } \\
\text { Normaal gewicht }(18.5-24.9) \\
\text { Overgewicht }(25.0-29.9) \\
\text { Obesitas }(\geq 30.0)\end{array}$ & $\begin{array}{l}1 \text { (referentie) } \\
0.87(0.61,1.24) \\
0.69(0.46,1.05)\end{array}$ & $\begin{array}{l}p=0.17 \\
p=0.22\end{array}$ & 2.91 \\
\hline $\begin{array}{l}\text { Roken - Nee } \\
\text { Roken - Gestopt } \\
\text { Roken - Ja }\end{array}$ & $\begin{array}{l}1 \text { (referentie) } \\
0.40(0.22,0.70) \\
0.29(0.15,0.61)\end{array}$ & $\begin{array}{l}p<0.01 \\
p<0.01\end{array}$ & 12.31 \\
\hline $\begin{array}{l}\text { Alcohol - Nee } \\
\text { Alcohol - Ja }\end{array}$ & $\begin{array}{l}1 \text { (referentie) } \\
1.23(0.88,1.72)\end{array}$ & $p=0.22$ & 1.48 \\
\hline $\begin{array}{l}\text { Vermoeidheid - Ja } \\
\text { Vermoeidheid - Nee }\end{array}$ & $\begin{array}{l}0.90(0.53,1.55) \\
1 \text { (referentie) }\end{array}$ & $p=0.71$ & 0.14 \\
\hline $\begin{array}{l}\text { Spierpijn - Ja } \\
\text { Spierpijn - Nee }\end{array}$ & $\begin{array}{l}1.12(0.79,1.52) \\
1 \text { (referentie) }\end{array}$ & $p=0.53$ & 0.40 \\
\hline $\begin{array}{l}\text { Kortademig - Ja } \\
\text { Kortademig - Nee }\end{array}$ & $\begin{array}{l}0.54(0.38,0.76) \\
1 \text { (referentie) }\end{array}$ & $p<0.01$ & 12.23 \\
\hline $\begin{array}{l}\text { Gastro-intestinale klachten - Ja } \\
\text { Gastro-intestinale klachten - Nee }\end{array}$ & $\begin{array}{l}0.59(0.41,0.85) \\
1 \text { (referentie) }\end{array}$ & $p<0.01$ & 8.19 \\
\hline $\begin{array}{l}\text { Reuk- en/of smaakverlies - Ja } \\
\text { Reuk- en/of smaakverlies - Nee }\end{array}$ & $\begin{array}{l}0.69(0.50,0.96) \\
1 \text { (referentie) }\end{array}$ & $p=0.03$ & 5.00 \\
\hline $\begin{array}{l}\text { Opname ziekenhuis - Ja } \\
\text { Opname ziekenhuis - Nee }\end{array}$ & $\begin{array}{l}0.35(0.16,0.75) \\
1 \text { (referentie) }\end{array}$ & $p=0.01$ & 7.30 \\
\hline
\end{tabular}

$\mathrm{HR}=$ Hazard Ratio; $\mathrm{BI}=$ betrouwbaarheidsinterval opleidingsniveau en sporten waren niet geassocieerd met de tijd tot volledig herstel na COVID-19.

Van de ziektegebonden variabelen waren vermoeidheid, kortademigheid, spierpijn, gastro-intestinale klachten, reuk- en/of smaakverlies en opname in een ziekenhuis geassocieerd met een langere verzuimduur. Een positieve COVID-test, koorts, verkouden, keelpijn, hoesten en hoofdpijn waren niet geassocieerd met de tijd tot volledig herstel.

In de multivariate analyse (tabel 3) bleken roken (Wald 12.31) en kortademigheid (Wald 12.23) de meest stabiele voorspellers van een lange verzuimduur, gevolgd door gastro-intestinale klachten (Wald 8.19) en ziekenhuisopname (Wald 7.30).

\section{Discussie}

Verzuim door COVID-19-infectie duurt lang. De gemiddelde verzuimduur was 79.1 (SD 63.1) dagen. Van de werknemers verzuimde 70\% langer dan een maand, 56\% langer dan twee maanden en 50\% langer dan drie maanden; $37 \%$ van de deelnemers is na 6 maanden nog steeds niet volledig hersteld. Mannelijk geslacht, overgewicht, roken, klachten (vermoeidheid, spierpijn, kortademigheid, gastro-intestinale klachten, reuk en/of smaakverlies) en ziekenhuisopname waren geassocieerd met een langere verzuimduur. Bij multivariate analyse blijken kortademigheid en roken de belangrijkste voorspellers van lang verzuim met COVID-19.

Er is weinig bekend over COVID-19 en verzuim. De Britse National Health Service (NHS) presenteerde in april/mei 2020 een verzuim van $6.2 \%$ waar hun verzuim normaal rond de $4 \%$ schommelt. ${ }^{7}$ Het gaat daarbij niet alleen om verzuim door positief getest personeel, maar ook om medewerkers in quarantaine of met klachten suspect voor COVID-19-infectie. Dat COVID-19 gepaard gaat met meer verzuim herkennen we ook in Nederland en is op zich een gegeven waar de bedrijfsarts in de praktijk niet zoveel mee kan. Voor bedrijfsartsen is interessanter om te weten welke factoren samenhangen met lang verzuim door COVID-19. Khonyongwa et al. ${ }^{8}$ vonden een significant effect van leeftijd en de COVID-19-testuitslag in een klinische setting. Onze studie toont dat leeftijd en een positieve COVID-19-test in de bedrijfsgeneeskundige setting niet voorspellend zijn voor de verzuimduur met COVID-19. Dit heeft waarschijnlijk te maken met het feit dat mensen met het hoogste risico (leeftijd boven de 70 jaar) niet meer tot de beroepsbevolking behoren. In onze studie waren kortademigheid, koorts en vermoeidheid de meest genoemde COVID-19-klachten. Uit de studie van Sudre et $\mathrm{a}^{9}$ komt dat vermoeidheid, kortademigheid, hoofdpijn en reuk- en smaakverlies geassocieerd worden met langdurige ziekte bij COVID-19. Vooral het aantal klachten in de eerste ziekteweek is volgens Sudre et al. voorspellend voor de duur van verzuim bij COVID-19. ${ }^{9}$ 
Een predictiemodel van leeftijd, geslacht en aantal klachten in de eerste ziekteweek had een Area Under the ROC Curve (AUC) van 0.76, wat betekent dat het model in $76 \%$ van de gevallen juist onderscheid maakt tussen kort en lang verzuim met COVID-19. Daarnaast is in ons onderzoek roken een belangrijke voorspeller van een langere verzuimduur. Dat kortademigheid en roken samenhangen met een lange verzuimduur past bij het feit dat COVID-19 vooral een luchtweginfectie is, hoewel inmiddels steeds duidelijker wordt dat ook andere orgaansystemen betrokken kunnen raken. Vanuit dat kader is het voor de bedrijfsarts interessant om te weten dat in ons onderzoek gastro-intestinale klachten (misselijkheid en diarree) ook geassocieerd waren met een langere duur van verzuim door COVID-19.

\section{Sterke punten en beperkingen}

Voor dit onderzoek zijn data verzameld van de ziekmeldingen door COVID-19 uit de eerste golf van de pandemie. Hiernaar is tot nu toe weinig of geen onderzoek gedaan. Kanttekening bij de kwaliteit van de gegevens is dat in de eerste maanden in Nederland een zeer minimaal COVID-19-testbeleid is geweest. Onze resultaten tonen dat destijds iets meer dan de helft (56\%) van de deelnemers met COVID-19-klachten daadwerkelijk getest is. Veel COVID-19-diagnoses zijn gesteld door beoordeling van klachten en ziektebeloop door een huisarts, zonder gebruik te kunnen maken van een diagnostische test. Daar komt bij dat we voor dit onderzoek deelnemers vanuit de verzuimregistratie hebben opgespoord. De diagnosecode (R605) wordt vaak pas toegekend als verzuim langer dan 1 tot 2 weken duurt. Ook kan het zijn dat mensen die kortdurend relatief milde klachten hebben gehad het niet meer nodig vonden om de vragenlijst in te vullen. Dat betekent dat mensen met lichte COVID-19-klachten of kort verzuim ondervertegenwoordigd zouden kunnen zijn in de studiepopulatie. Daarnaast is het denkbaar dat werknemers met CAScode R605 alleen niet werkten omdat ze tot een hoog risicogroep behoorden of in thuisquarantaine zaten. Maar deze vorm van selectiebias wordt niet waarschijnlijk geacht, omdat alle deelnemers klachten passend bij COVID-19 rapporteerden. De lage respons rate (33\%) vergroot de kans op selectiebias wel aanzienlijk bijvoorbeeld door een ondervertegenwoordiging van werknemers die zich nog te ziek voelden voor deelname. Hoewel, zo'n ondervertegenwoordiging in deze studie niet erg waarschijnlijk lijkt te zijn, omdat $15 \%$ van de deelnemers - met een gemiddelde leeftijd van 49.7 jaar - opgenomen is geweest in een ziekenhuis. Ter vergelijking, de NOS.nl meldde destijds dat een paar procent van de 20-40-jarigen met COVID-19 werd opgenomen in een ziekenhuis; dat iets minder dan $10 \%$ van de 40-49-jarigen werd opgenomen, iets meer dan $15 \%$ van de $50-59$-jarigen en iets meer dan $20 \%$ van de $60-69$ jarigen. ${ }^{10}$
Verder zien we dat een derde van de deelnemers, ziekgemeld met CAScode R605 een negatieve testuitslag had. We hebben ervoor gekozen om toch alle deelnemers te includeren, omdat anders de populatie te klein zou worden voor een multivariate analyse. Dat betekent dat de resultaten van deze studie representatief zijn voor werknemers waarvoor de bedrijfsarts een CAScode R605 in de verzuimregistratie invoerde.

Hoewel het begrip van de vragen in de vragenlijst in een kleinschalige pilot was uitgetest en bijgesteld, bleek tijdens het onderzoek toch dat enkele vragen over leefstijlfactoren op verschillende manieren geïnterpreteerd konden worden (voor of na de COVID-19-infectie), waardoor er informatiebias op deze punten kan zijn ontstaan. Dit betekent dat de resultaten met betrekking tot roken, alcoholgebruik en sporten mogelijk niet helemaal betrouwbaar zijn. Hiermee dient rekening te worden gehouden bij de interpretatie van de resultaten.

Het aantal verzuimdagen en de hersteldmelding zijn uitgevraagd via de vragenlijst en niet uit het verzuimsysteem gehaald. Dit is gedaan om de aanvraagprocedure voor het onderzoek zo kort mogelijk te houden, zodat het onderzoek op korte termijn uitgevoerd kon worden. Op deze manier was het afdoende om alleen NAW-gegevens op te vragen waarmee de vragenlijst verstuurd kon worden. Dit heeft mogelijk ook enige recall-bias opgeleverd, hoewel zelf gerapporteerd ziekteverzuim in grootschalig steekproefonderzoek als een betrouwbaar alternatief werd gekenschetst voor geregistreerd ziekteverzuim. ${ }^{11}$ Daarnaast omvatten de respondenten zowel personen die hersteld waren ten tijde van het invullen van de vragenlijst, als personen die nog niet hersteld waren en wellicht nog maar kort ziek. Van die laatste categorie is de feitelijke hersteldatum niet nagegaan. Mogelijk dat dit tot een onderschatting van de (gemiddelde) verzuimduur heeft geleid.

\section{Aanbevelingen voor de praktijk}

In de praktijk moeten we rekening moeten houden met langdurig verzuim na COVID-19. In de spreekkamer is het voor de bedrijfsarts van belang om factoren uit te vragen die samenhangen met een lange verzuimduur bij COVID-19. Het is vooral belangrijk dat de bedrijfsarts roken en kortademigheid uitvraagt, aangezien dat de sterkste voorspellers zijn. Ook gastro-intestinale klachten, reuk- en/of smaakverlies en ziekenhuisopname zijn significante voorspellers van lang verzuim na COVID-19. Andere veel voorkomende COVID-19-klachten zoals koorts en vermoeidheid zijn in multivariate analyse niet significant met de verzuimduur geassocieerd. Volgens onze resultaten hoeft de bedrijfsarts dus niet specifiek naar vermoeidheid te vragen. Ook hoesten, keelpijn en hoofdpijn waren niet geassocieerd met de verzuimduur na COVID-19-infectie. Door de juiste klachten gericht uit te vragen kan de bedrijfsarts de prognose beter inschatten, 
en indien nodig sneller interventies in gang zetten met als doel om het herstel te bevorderen en zo het verzuim te verkorten.

Dit onderzoek is uitgevoerd als onderdeel van de opleiding tot arts Arbeid en Gezondheid bij de NSPOH. Er is geen sprake van financiële of andere vormen van belangenconflicten. Het onderzoek is mede tot stand gekomen door middel van deskundige ondersteuning vanuit de Arbo Unie.

\section{Literatuur}

1. LCI-richtlijn van het RIVM [Internet]. LCI richtlijnen. 2020 [cited 16 April 2021]. Available from: https://lci.rivm.nl/ richtlijnen/covid-19.

2. Ontwikkeling COVID-19 in grafieken, tabblad "vanaf 27 februari 2020” [Internet]. Rivm.nl. [cited 2021 Jan 19]. Available from: https://www.rivm.nl/coronavirus-covid-19/ grafieken.

3. WHO Director-General's opening remarks at the media briefing on COVID-19 - 11 March 2020 [Internet]. Who.int. [cited 16 April 2021]. Available from: https://www.who.int/director-general/speeches/detail/who-director-general-s-openingremarks-at-the-media-briefing-on-covid-19 - 11-march-2020.

4. Centraal Bureau voor Statistiek: Ziekteverzuim eerste kwartaal hoogste in 17 jaar. [Internet]. 2020 [cited 16 April 2021]. Available from: https://www.cbs.nl/nl-nl/ nieuws/2020/19/ziekteverzuim-eerste-kwartaal-hoogste-in17-jaar.

5. Duizenden patiënten met 'milde' coronaklachten zijn wekenlang ziek [Internet]. Nos.nl. 2020 [cited 16 April 2021]. Available from: https://nos.nl/artikel/2334166-duizenden-patienten-met-milde-coronaklachten-zijn-wekenlang-ziek. html.

6. Body mass index - BMI. 2021 [cited 16 April 2021]; Available from: https://www.euro.who.int/en/health-topics/ disease-prevention/nutrition/a-healthy-lifestyle/body-massindex-bmi.

7. Appleby J. NHS sickness absence during the covid-19 pandemic. British Medical Journal 2021; 372:n471.

8. Khonyongwa K, Taori SK, Soares A, Desai N, Sudhanva M, Bernal W, Schelenz S, Curran LA. Incidence en outcomes of healthcare-associated COVID-19 infections: significance of delayed diagnosis en correlation with staff absence. Journal of Hospital Infections 2020; 106: $663-672$.
9. Sudre CH, Murray B, Varsavsky T, Graham MS, Penfold RS, Bowyer RC, et al. Attributes and predictors of long COVID. Nature Medicine 2021 Mar 10. doi: 10.1038/s41591-02101292-y. Online ahead of print.

10. Duizenden coronapatiënten in ziekenhuis: ze zijn jonger en liggen er minder lang [Internet]. Nos.nl 2021 [cited 16 April 2021]. Available from: https://nos.nl/collectie/13824/artikel/2351381-duizend-coronapatienten-in-ziekenhuis-ze-zijnjonger-en-liggen-er-minder-lang.

11. De Vroome EMM, de Koppes LLJ, Smulders PGW, van den Bossche SNJ. Verzuimmeting via zelfrapportage en registratie: verschillen tussen de Nationale Enquete Arbeidsomstandigheden en de Nationale Verzuim Statistiek. Tijdschrift Sociale Geneeskunde 2010;88:71-78.

\section{Abstract \\ Objective: Which factors are associated with the time to full return-to-work of workers on sick leave due to COVID-19?}

Methods: In a cross-sectional study 349 employees on sick leave due to COVID-19 were included. They filled out a questionnaire once about person-related factors, disease-related factors and sick leave. Associations with the duration of sick leave were analyzed with univariate and multivariate Cox regression analyses. A hazard ratio $(\mathrm{HR})<1$ indicates at a smaller chance of recovery or a longer duration of sick leave. Results: The person-related factors male gender, overweight and smoking were univariately associated with a longer time to return-to-work. The disease-related factors fatigue, muscular pain, shortage of breath, gastro-intestinal complaints, loss of smell and/or taste and hospitalization were also associated with longer sick leave. From multivariate analyses, shortage of breath and smoking appeared the most important predictors of a longer time to full return-to-work. Conclusion: Occupational physicians should explore shortage of breath and smoking behavior of patients and pay attention to fatigue, muscular pain, gastro-intestinal complaints, loss of smell and/or taste and hospitalization as prognostic factors for the duration of sick leave after COVID-19. 